\title{
Harwood's Francolin Francolinus harwoodi: recent observations on its status, distribution, habitat requirements, behaviour and threats
}

\author{
P.A. ROBERTSON, YILMA DELLELEGN, SILESHI DEJENE, ANTENEH \\ SHIMELIS, TADESSE W/MARIAM and MILLION ALEMAYEHU
}

\begin{abstract}
Summary
In May 1996 the authors carried out surveys of Harwood's Francolin Francolinus harwoodi, a threatened and restricted-range species, within the upper reaches of the Abay Basin, North Shoa Administrative Region, Ethiopia. The species is known from a small range in the Abay Basin but has not been reliably recorded away from a single site in the Jema Valley since 1930. Harwood's Francolin was found in the Jema Valley and valleys of adjacent river systems and, according to local reports, its range extends northwards into Southern Wello Administrative Region, a northerly extension of its previously known range. The species was found to be locally abundant, with transect counts giving a maximum density estimate of 92 birds $/ \mathrm{km}^{2}$.
\end{abstract}

Typha beds had been considered a crucial element in the species's habitat, but our observations suggest that although Typha beds are sometimes used they are not an essential requirement. The main threat to the species's survival appears to be from clearance of thorn scrub rather than from clearance of Typha beds. Additional threats come from hunting for food and for sale at market, and collection of eggs.

Observations of courtship and mating in May and local reports of eggs in October indicate an earlier start to the breeding season than previously reported (first egg dates in December). The species may have two broods or have an extended, non-synchronous breeding season, timed to coincide with the rainy season and early dry season (MayDecember). Birds were observed to be highly gregarious and observations of courtship suggest that the species may be polygamous.

Recommendations are given for the conservation of the species, including further survey work and collaboration with local communities to identify and protect key areas of habitat.

\section{Introduction}

Harwood's Francolin Francolinus harwoodi is endemic to Ethiopia and has an extremely restricted range. It is one of four restricted-range species confined to the Central Ethiopian Highlands Endemic Bird Area (ICBP 1992). It is listed in Birds to watch 2: the world list of threatened birds (Collar et al. 1994) as 
Vulnerable, with the chief threats considered to be destruction of its Typha habitat and hunting pressure.

As a part of the Ethiopian Important Bird Areas project being carried out by the Ethiopian Wildlife and Natural History Society (EWNHS), the authors visited the Jema Valley $\left(9058^{\prime} \mathrm{N}, 38055^{\prime} \mathrm{E}\right)$ and areas to the north, in central Ethiopia, from 27 to 29 May 1996. The aim of the visit was to assess the current status of Harwood's Francolin and its habitat in the Jema Valley (the only site from which there are recent records) and to search for the species at neighbouring sites.

\section{Localities for the species}

The positions of past, present and possible localities of Harwood's Francolin are shown on Figure 1. Since the description in 1899 of a specimen from the highlands of Ethiopia, at Aheafeg (also Ahaia Fej or Haiafegg) $\left(10^{\circ} 13^{\prime} \mathrm{N}\right.$, $39^{\circ} 18^{\prime} \mathrm{E}$ ) (Blundell and Lovett 1899 ), Harwood's Francolin has been reported from only four other localities; Jemmu Valley (Jema Valley) $\left(9^{\circ} 58^{\prime} \mathrm{N}, 38^{\circ} 55^{\prime} \mathrm{E}\right)$, near Bichana $\left(10^{\circ} 26^{\prime} \mathrm{N}, 38^{\circ} 16^{\prime} \mathrm{E}\right)$, Kalo Ford $\left(9^{\circ} 54^{\prime} \mathrm{N}\right.$, $\left.37^{\circ} 57^{\prime} \mathrm{E}\right)$, and Muger River $\left(9^{\circ} 28^{\prime} \mathrm{N}, 38^{\circ} 36^{\prime} \mathrm{E}\right)$ (Urban et al. 1986). Possible sight records from Gibe Gorge $\left(8^{\circ} 15^{\prime} \mathrm{N}, 37^{\circ} 55^{\prime} \mathrm{E}\right)$ and $39 \mathrm{~km}$ north-east of Dembidollo (Ash 1978) were later discounted by the same author (Ash and Gullick 1989). Recent sightings have come from the Jema Valley site (Tyler and Tyler 1975; Ash 1978; Ash and Gullick 1989, J.D. Atkins pers. 'comm.). Away from this site, the most recent record is that from Kalo Ford in 1930 (Cheeseman and Sclater 1935).

During the current survey Harwood's Francolin was recorded from three sites: Afer Bayine ( $10^{\circ} 15^{\prime} \mathrm{N}, 38^{\circ} 58^{\prime} \mathrm{E}$; c. $1800 \mathrm{~m}$ a.s.l.; 8 birds in 1 hour), $37 \mathrm{~km}$ north of the Jema site, north of Alem Katema, $22 \mathrm{~km}$ by road on the newly constructed Alem Katema-Gundo Meskel road; Jara River bridge ( $10^{\circ} 14^{\prime} \mathrm{N}, 38^{\circ} 5^{\prime} \mathrm{E}$; $1450-1500$ $\mathrm{m}$ a.s.l.; 33 birds in 1 hour), $34 \mathrm{~km}$ north of the Jema site, north of Alem Katema, $16 \mathrm{~km}$ by road on the Alem Katema-Gundo Meskel road; Jema River bridge $\left(9^{\circ} 58^{\prime} \mathrm{N}, 38^{\circ} 55^{\prime} \mathrm{E}\right.$; $1,300-1,320 \mathrm{~m}$ a.s.l.; 7 birds in 1 hour). In addition, there is a recent record (November, 1995) from $6.5 \mathrm{~km}$ south-east of Lemi $\left(9^{\circ} 47^{\prime} \mathrm{N}, 38^{\circ} 5^{\prime} \mathrm{E}\right.$; 2,600 $\mathrm{m}$ a.s.l.) (J.D. Atkins verbally).

Harwood's Francolin was found to be well known to local people, many of whom were able to pick it out from the field guide and give a convincing description, although they apparently use the same name ("Soren" meaning Red-legged Francolin) for both Harwood's Francolin and Clapperton's Francolin $F$. clappertoni. They reported the species to be present at the following six additional areas: Garda (c. $5 \mathrm{~km}$ ENE of Afer Bayine), Wenchit River $\left(10^{\circ} 8 \mathrm{~N}\right.$, $38^{\circ} 5^{\prime} \mathrm{E} ; 1,300-1,320 \mathrm{~m}$ a.s.l.), Meranya $\left(10^{\circ} 12^{\prime} \mathrm{N}, 39^{\circ} \mathrm{O} 5^{\prime} \mathrm{E} ; c .2,500 \mathrm{~m}\right.$ a.s.l.), Rema $\left(10^{\circ} 18^{\prime} \mathrm{N}, 38^{\circ} 55^{\prime} \mathrm{E}\right.$; c. $2,000 \mathrm{~m}$ a.s.1.), Jema basin away from the known site, Were Ilu ( $\left.10038^{\prime} \mathrm{N}, 38056^{\prime} \mathrm{E}\right)$, and elsewhere in Southern Wello Administrative Region. The latter location lies to the north of the currently known range. The other localities from which the species has been recorded by, or reported to, the authors lie within the known range and suggest that the species is widespread within this range. 


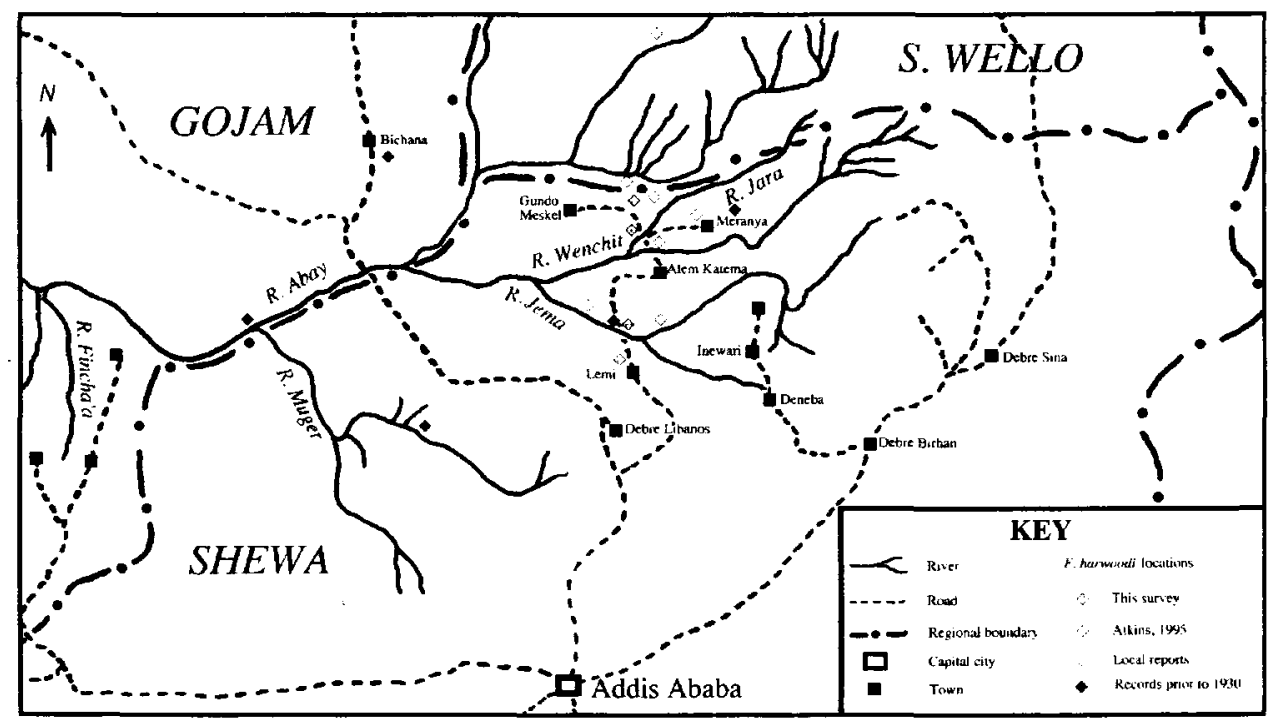

Figure 1. The Abay basin, Ethiopia, with localities of Harwood's Francolin.

\section{Description of sites of recent records}

\section{Jema Valley}

The Jema Valley site is at the base of a steep sided gorge, with a wide $(c .12 \mathrm{~km})$ valley bottom of undulating ground and narrow flood plains. The rocky hillsides within the valley and the sides of the gorge are principally composed of limestone. Much of the valley bottom is cultivated for sorghum, sesame and safflower oilseeds. A sparse cover of Calotropis procera and grass grows in fallow areas one year after abandonment. Cultivated and previously cleared land covered $c .80 \%$ of the area surveyed. There are relatively small patches of natural vegetation, principally thorn scrub, mainly confined to steeper slopes, and some larger trees close to the river. The dominant species of the thorn scrub is Acacia seyal, with Sterculia africana, Tamarindus indica, Commiphora sp., and Ziziphus spina-christi (J.D. Atkins and S. Edwards unpubl. report 1995). There is an extensive Typha bed ( $c .4 \mathrm{~km} \times 300 \mathrm{~m}$ ) along the Bersena River which bounds the site and flows into the Jema River by the bridge.

\section{Jara Valley}

The Jara Valley site is at the bottom of a deep but relatively shallow-sided valley. It is similar to the Jema Valley site in that it consists of a narrow river flood plain and undulating, rocky ground. Much of the area, even up the valley sides, is covered with thorn scrub and woodland which is both denser and more extensive than that found at the Jema Valley site. The principal species are Acacia seyal, Commiphora sp., Ziziphus spina-christi, Combretum aculeatum and Ficus thonningii. There is a small Typha bed (c. $0.5 \mathrm{~km} \times 15 \mathrm{~m})$ bordering the river. 
There is cultivation, principally for sorghum, at the site but the area of cultivated and previously cleared land (c. $40 \%$ of the area surveyed) is less extensive than at Jema Valley. This site has come under agricultural pressure relatively recently, with people travelling from surrounding highland areas to farm the land.

\section{Afer Bayine}

The site at Afer Bayine differs from the two previous ones in that it is not located around a permanent river and consequently has no Typha beds. It is on a hillside at the base of which is a seasonal stream which drains into the Jara River. The stream was dry at the time of our visit. There is extensive thorn scrub on the hillside, composed principally of Acacia seyal, Terminalia brownii, Grewia bicolor, Grewia ferruginea, Balanites aegyptiaca, Combretum aculeatum, Clerodendron myricoides, Maytenus ozatus, Cordia africana, Sizygium guineense and Euclea schimperi. The extent of cultivation was less than at the two previous sites (c. $25 \%$ of the area surveyed under cultivation or recently cultivated land), but there was also grazing of cattle and goats and extensive collection of fuelwood. A small settlement of five houses had recently been established.

\section{Density of individuals at two sites}

Harwood's Francolin was censused at two sites using transect counts with full distance recording (Bibby et al. 1992). Existing paths and tracks were used and for all birds observed the perpendicular distance from the track to the bird or to the centre of a group of birds at the moment when the birds were first observed was estimated. The length of transects walked was measured using a pedometer calibrated against a measured walk of $200 \mathrm{~m}$. At each site an area of approximately $5 \mathrm{~km}$ of valley bottom, centred on the bridges crossing the Jema and Jara Rivers and up to $1 \mathrm{~km}$ from them, was surveyed. Within this area two transects each of approximately $3.5 \mathrm{~km}$ were walked simultaneously by two teams of three observers working as a group. At Jara Valley two transects were walked simultaneously between $17 \mathrm{~h} 10$ and $18 \mathrm{~h} 10$ on 28 May 1996 and at Jema Valley two transects were walked simultaneously between o6h4o and o7h4o on 29 May 1996. The timing of the surveys, up to 50 minutes before sunset and from 45 minutes after sunrise, avoided the period when birds would be at roost or moving to or from the roost, but coincided with periods of high activity. The results of these surveys were analysed using the programme DISTANCE (Laake et al. 1993) and are shown in Table 1. Although the results cannot be extrapolated to the Jema and Jara Valleys as a whole they provide a useful basis for comparison of the habitats at the two different sites.

Differences in density estimates between the two sites were not considered to be a result of the difference in timing of the surveys (morning and evening) as an almost equal number of birds were seen during 1 hour in the morning (informal counts) and $\mathrm{I}$ hour in the evening (survey) at Jara Valley (a.m. 35 birds, p.m. 33 birds). In addition, although greater activity may be expected in the morning than in the evening, a higher density of Harwood's Francolin was found during the evening survey at Jara Valley than during the morning survey at Jema Valley. 
Table 1. Density of Hurwood's Francolin and habitat diffrences in the Jara and Jema Valleys

\begin{tabular}{lcccc}
\hline Site & $\begin{array}{c}\text { Density } \pm \text { S.E. } \\
\left(\text { birds } / \mathrm{km}^{2}\right)\end{array}$ & $\begin{array}{c}\text { Proportion of } \\
\text { thorn scrub (\%) }\end{array}$ & $\begin{array}{c}\text { Proportion of fallow/ } \\
\text { cultivated land (\%) }\end{array}$ & $\begin{array}{c}\text { Area of Typha } \\
\text { bed }\end{array}$ \\
\hline Jara & $92 \pm 37.50$ & 60 & 40 & $0.5 \mathrm{~km} \times 15 \mathrm{~m}$ \\
Jema & $8 \pm 2.88$ & 20 & 80 & $4 \mathrm{~km} \times 300 \mathrm{~m}$ \\
\hline
\end{tabular}

The difference in the density between the two sites (Table 1) is considered to be principally the result of differences in habitat, although differences in hunting and disturbance pressure may also play a role, as human presence appeared to be greater at the Jema than at the Jara Valley site. The area surveyed at Jara Valley had a limited Typha bed (c. $0.5 \mathrm{~km} \times 15 \mathrm{~m}$ ), but the surrounding slopes were mostly well covered with thorn scrub with a relatively small area of cultivation and fallow land (c. $40 \%$ of the total area) interspersed with thorn scrub (Table 1). At the Jema Valley site the Typha beds were considerably more extensive $(c .4 \mathrm{~km} \times 300 \mathrm{~m})$ but the surrounding land was much more extensively cultivated or fallow (c. $80 \%$ of the total area) with relatively restricted areas of thorn scrub in a narrow strip adjacent to the main river and on steep, rocky and relatively inaccessible ground. Given the much higher density of birds at the Jara Valley site, this may indicate that the extent of thorn scrub is more important than the extent of Typha beds in determining the density of Harwood's Francolin (Table 1).

\section{Behaviour}

Birds were observed between $06 \mathrm{~h} 15$ and 08 hoo and between 17 hoo and 19 h15 (27-29 May 1996). Searches later in the morning and earlier in the evening were unsuccessful. Birds were heard calling between o6h 15 and $07 \mathrm{~h}_{3} \mathrm{O}$ and between 18 hoo and 19h15, with calls being more frequent closer to dawn and dusk. They usually called from cover and the only bird seen perching off the ground (on a boulder $c .0 .3 \mathrm{~m}$ high) was not seen to call. The call was a rasping "karsh" repeated 3 or 4 times, with a long pause before calling again.

The birds were easy to see, as they fed in the open, but could not easily be approached closer than $10-15 \mathrm{~m}$. When alarmed they adopted an upright stance if the danger was not immediate and then crouched low to the ground and crept into the cover of thorn scrub. If they were surprised at close quarters, they flew for 10-20 $\mathrm{m}$ and then ran off into the cover of thorn scrub. No birds were seen to seek the cover of Typha beds as reported by Ash (1978).

Birds were seen singly and in groups of between two and eight individuals (Fig. 2). One group of eight birds was seen feeding in association with a group of 15 Helmeted Guineafowl Numida meleagris. Harwood's Francolin was not seen to associate with any other francolin, and indeed the only other francolin seen in the area was a single Erckel's Francolin F. erckeli in a highland area $(c .2,500 \mathrm{~m}$ a.s.l.) at Meranya. One group of five birds ( 1 male and 4 females) were seen involved in courtship and mating. The male lowered his head and drooped his wings, approaching the female making a low clucking call. The female initially walked away before the male eventually mounted her. The male was seen to approach several of the females but only one mating was observed. This 


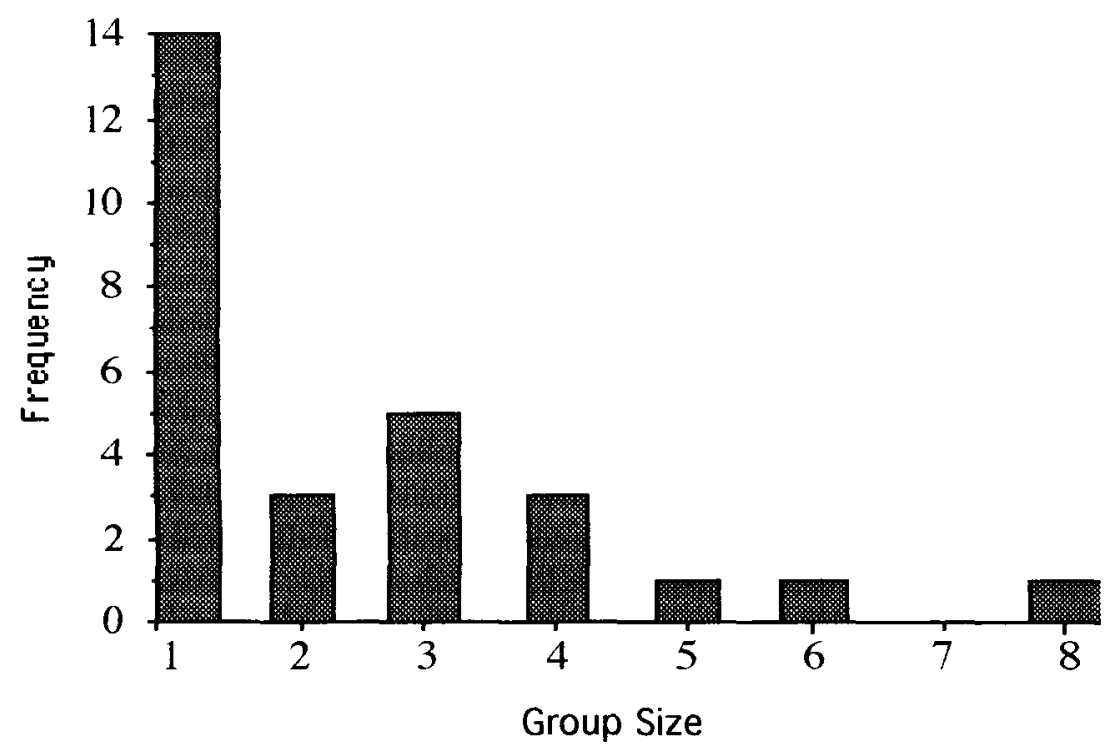

Fig. 2 The frequency of different group sizes of Harwood's Francolin.

observation implies that the breeding season begins in May-June, much earlier than suggested by Ash (1978) and Ash and Gullick (1989) who report first laying in December. The suggestion of an earlier breeding season is supported by the observations of local people who reported that the birds had eggs in October. The breeding season of Harwood's Francolin could, therefore, be similar to that of $F$. clappertoni in Ethiopia, for which egg laying is reported as April-December (Urban et al. 1986). The observation of Harwood's Francolin feeding in groups during the breeding season (over $65 \%$ of birds were in groups of three or more) and of a single male attempting to mate with more than one female may indicate that the species is polygamous. No other African francolin is known to be polygamous (Urban et al. 1986).

No birds were seen in Typha, although the density of the vegetation would in any case make such observations unlikely. However, two individuals and a group of four birds were observed moving from surrounding habitats towards a Typha bed in the evening (c. I8hoo), and one individual and a group of three birds were observed moving from areas immediately adjacent to Typha beds into surrounding habitats between $06 \mathrm{~h}_{30}$ and o7h15. This suggests that some birds were roosting in Typha beds, as reported by Ash (1978). However, birds were also heard calling from the cover of thorn scrub after sunset, and were seen at a site (Afer Bayine) where there were no Typha beds, suggesting that although Typha beds are sometimes used for roosting they are not an essential part of the habitat.

Birds were seen feeding most frequently in harvested sorghum fields with adjacent thorn scrub, but were also observed feeding in sparse grass, bare stony/ sandy soil and in organic litter among scattered thorn scrub. They fed by scraping shallow depressions in the ground with their feet and then pecking at exposed food items, presumably seeds and invertebrates. 


\section{Threats}

Considerable clearance of trees and thorn scrub for cultivation, fuelwood, construction and supposedly to reduce populations of rodent crop pests, appears to be the major threat to the survival of Harwood's Francolin. Some areas of Typha are cleared annually to allow the cultivation of cotton on the moist soil and are also cut to provide material for thatching. Although the Typha beds have considerable powers of regeneration, their area is gradually being reduced (Ash 1978, J.D. Atkins and S. Edwards unpubl. report 1995). However, the loss of Typha beds, considered to be the critical threat to the species by Ash (1978) and Ash and Gullick (1989) may be less significant than the clearance or degradation of the surrounding areas of thorn scrub.

The birds are also hunted for food (Ash 1978, Ash and Gullick 1989) and their meat is prized both for its flavour and supposed medicinal properties. They are sometimes caught for sale at local markets. Birds are usually hunted by setting a leg snare which is sprung by a bent-over branch. This type of hunting is largely restricted to the rainy season (June-September) because branches are too brittle and the ground too hard to set a trap during the dry season. However, during the dry season birds are sometimes hunted by throwing stones. Their eggs are also collected for food.

\section{Recommendations}

1. Further surveys are needed across the species's range, particularly to investigate its habitat requirements, the relative importance of different threats and identify core areas for protection of the species. Such surveys should concentrate on areas where the species is reported by local people and areas of potentially suitable habitat identified from aerial photographs.

2. An awareness programme should be initiated within the range of Harwood's Francolin, highlighting the uniqueness of the species and linking its threatened status to the destruction of its habitat on hillsides, which also leads to soil erosion.

3. Any conservation programme should not seek to prevent all exploitation of the species, but should endeavour to introduce sustainable utilization of Harwood's Francolin, and hence give a direct benefit to the local communities from protecting its habitat.

4. The zonal (Debre Birhan) and Woreda (Alem Katema) offices for administration and agriculture should act, in collaboration with local communities, to protect key areas of the species' habitat, following recommendations from a wider survey.

\section{Acknowledgements}

We are especially indebted to Ato Zelealem Tefera of the Ethiopian Wildlife and Natural History Society who reported to us the probable presence of Harwood's Francolin in the areas visited. Ato Ephraim acted as a guide in the Afer Bayine area. Ato Tawabe Ashenafi and Ato Aberre W/Giorgis, the project drivers, safely got us around the difficult terrain. The Ethiopian Important Bird Areas project is run by EWNHS, the BirdLife Partner in Ethiopia, and is funded by the European Union (DG VIII B7-5040). 


\section{References}

Ash, J. S. (1978) The undescribed female of Harwood's Francolin Francolinus harwoodi and other observations on the species. Bull. Brit. Orn. Club 98: 1-15.

Ash, J. S. and Gullick, T. M. (1989) The present situation regarding the endemic breeding birds of Ethiopia. Scopus 13: 90-96.

Bibby, C. J., Burgess, N. D. and Hill, D. A. (1992) Bird census techniques. London: Academic Press.

Blundell, A. and Lovett, C. (I899) A new species of francolin from Abyssinia. Bull. Brit. Orn. Club 10: 22.

Cheeseman, R. E. and Sclater, W. L. (1935) On a collection of birds from north-western Abyssinia. Ibis 13: 151-191.

Collar, N. J., Crosby, M. J. and Stattersfield, A. J. (1994) Birds to watch 2: the world lst of threatened birds. Cambridge, U.K.: BirdLife International (BirdLife Conservation Series 4).

ICBP (1992) Putting biodiversity on the map: priority areas for global conservation. Cambridge, U.K.: International Council for Bird Preservation.

Laake, J. L., Buckland, S. T., Anderson, D. R. and Bunham, K. P. (1993) DISTANCE user's guide. Fort Collins, Colorado: Colorado Cooperative Fish and Wildlife Research Unit, Colorado State University.

Tyler, L. and Tyler, S. J. (1975) Recent bird records-for January. Ethiopian Wildlife and Natural History Society Newsletter 94: 5.

Urban, E. K., Fry, C. H. and Keith, S. (1986) The birds of Africa, 2. London: Academic Press.

PETER A. ROBERTSON

April Cottage, Well Lane, St. Margarets-at-Cliffe, Nr Dover, Kent CT15 6AA, U.K.

YILMA DELLELEGN, SILESHI DEJENE, ANTENEH SHIMELIS and TADESSE W/ MARIAM EWNHS

P.O. Box 60074, Addis Ababa, Ethiopia.

\section{MILLION ALEMAYEHU}

Dept. of Agricultural Development for North Shoa Administrative Zone, P.O. Box 12, Debre Birhan, North Shoa, Ethiopia. 